\title{
Synthesis and functional analysis of deferriferrichrysin derivatives: Application to colorimetric $\mathrm{pH}$ indicators.
}

\section{AUTHOR(S):}

Kobayashi, Yuka; Oishi, Shinya; Kobayashi, Kazuya; Ohno, Hiroaki; Tsutsumi, Hiroko; Hata, Yoji; Fujii, Nobutaka

\section{CITATION:}

Kobayashi, Yuka ... [et al]. Synthesis and functional analysis of deferriferrichrysin

derivatives: Application to colorimetric pH indicators.. Bioorganic \& medicinal chemistry 2013, 21(14): 4296-4300

\section{ISSUE DATE:}

2013-07-15

URL:

http://hdl.handle.net/2433/176374

\section{RIGHT:}

(C) 2013 Elsevier B.V.; This is not the published version. Please cite only the published version.; この論文は出版社版でありません。引用の際に は出版社版をご確認ご利用ください。 


\section{Synthesis and functional analysis of deferriferrichrysin derivatives: application to}

\section{colorimetric pH indicators}

Yuka Kobayashi ${ }^{\text {a }}$, Shinya Oishi ${ }^{\text {a,* }}$, Kazuya Kobayashi ${ }^{\text {a }}$, Hiroaki Ohno ${ }^{\text {a }}$, Hiroko Tsutsumi ${ }^{\text {b }}$, Yoji

Hata $^{\mathrm{b}}$, Nobutaka Fujii ${ }^{\mathrm{a}, *}$

${ }^{a}$ Graduate School of Pharmaceutical Sciences, Kyoto University, Sakyo-ku, Kyoto 606-8501, Japan

${ }^{\mathrm{b}}$ Gekkeikan Research Institute, Gekkeikan Sake Company, Fushimi-ku, Kyoto 612-8385, Japan

*Corresponding Authors:

Shinya Oishi, Ph.D. and Nobutaka Fujii, Ph.D.

Graduate School of Pharmaceutical Sciences

Kyoto University

Sakyo-ku, Kyoto, 606-8501, Japan

Tel: +81-75-753-4551; Fax: +81-75-753-4570,

E-mail (S.O.): soishi@pharm.kyoto-u.ac.jp; E-mail (N.F.): nfujii@pharm.kyoto-u.ac.jp 


\section{ABSTRACT}

Deferriferrichrysin belongs to the siderophore peptide family which are Fe(III)-coordinating cyclic peptides. The common structure of this family is three consecutive hydroxamate moieties, such as $N^{\delta}$-acetyl- $N^{\delta}$-hydroxy-L-ornithine (Aho). We have designed two deferriferrichrysin derivatives where three Aho residues were arranged as: cyclo(-Aho-Gly-Aho-Gly-Aho-Gly-) and cyclo(-Aho-Ser-Aho-Ser-Aho-Ser-). Comparative evaluation of the physicochemical properties of their Fe(III) complexes revealed that naturally occurring deferriferrichrysin formed a more stable Fe(III) complex when compared with the two derivatives. This result shows that three consecutive Aho residues are indispensable for high affinity Fe(III) binding by deferriferrichrysin. Of note, the observed $\mathrm{pH}$-dependent chromogenic response of the $\mathrm{Fe}(\mathrm{III})$ complexes of the derivatives suggests that these two derivatives should function as sensitive $\mathrm{pH}$ indicators in acidic environments.

Keywords: deferriferrichrysin, ferrichrome peptide, hydroxamate, iron complex, siderophore 


\section{Introduction}

Microbes produce Fe(III) selective chelators, called siderophores, ${ }^{1}$ to sequester Fe(III), which is necessary for cellular redox chemisty, ${ }^{2}$ but insoluble under physiological conditions. Over 500 siderophores have been isolated and classified according to coordinate groups and scaffolds. Deferriferrichrysin (1) is a cyclic hexapeptide siderophore with three $N^{\delta}$-acetyl- $N^{\delta}$-hydroxy-L-ornithine (Aho) residues that is produced by Aspergillus oryzae (Figure 1). ${ }^{3}$ Its Fe(III) complex, ferrichrysin (2), is a colorant in rice wine (sake). Deferriferrichrome (3) ${ }^{4}$ and deferriferrichrome A (4) $)^{5}$ are also hydroxamate-containing cyclic hexapeptides. The common feature of this siderophore family is the presence of three consecutive residues with Fe(III)-coordinating hydroxamate side-chains.

These Fe(III)-siderophore complexes are incorporated into the cytoplasm via ABC type transporters. ${ }^{1}$ Using this iron uptake system found in microbes, several siderophore-conjugated pharmaceuticals have been designed for a microbe selective drug delivery system. ${ }^{6-8}$ For example, an antibiotic with a triscatecholate siderophore (5) was taken up by Gram-negative bacteria species, including Pseudomonas aeruginosa. The mycobactin-artemisinin conjugate (6) was effective against drug resistant strains of Mycobacterium tuberculosis, in which Fe(III)-mediated Fenton-type radical formation from a mycobactin moiety was also the key active ingredient of this anti-tuberculosis conjugate. Thus, Fe(III)-siderophore complexes represent interesting pharmaceutical materials for antimicrobial agents.

In order to investigate the coordinating ability of three consecutive Aho residues in deferriferrichrysin (1), we have designed two deferriferrichrysin derivatives, cyclo(-Aho-Gly-Aho-Gly-Aho-Gly-) (7a) and cyclo(-Aho-Ser-Aho-Ser-Aho-Ser-) (7b). These two compounds contain three Aho residues interspersed by either Gly or Ser residues derived from deferriferrichrysin. In this article, we report the synthesis of these two deferriferrichrysin derivatives and the spectroscopic analysis of the physicochemical properties of the Fe(III) complexes. 


\section{Results and discussion}

\subsection{Synthesis of deferriferrichrysin derivatives}

In a previous study, we have established a facile synthetic approach to $N^{\alpha}$-Fmoc-protected $N^{\delta}$-acetyl- $N^{\delta}$-(tert-butoxy)-L-ornithine [Fmoc-Aho $\left.(t-\mathrm{Bu})-\mathrm{OH}\right] .{ }^{9}$ Using this amino acid component as a building block in Fmoc-based solid-phase peptide synthesis (SPPS), deferriferrichrysin (1) and deferriferrichrome (3) were synthesized. ${ }^{9}$ According to this protocol, hexapeptide resins 9a,b were prepared on 2-chlorotrityl [(2-Cl)Trt] resin (Scheme 1). Peptide elongation was performed by standard Fmoc-based SPPS using $N, N$ '-diisopropylcarbodiimide (DIC)/ $N$-hydroxybenzotriazole (HOBt). Treatment of the resin with 1,1,1,3,3,3-hexafluoro-2-propanol (HFIP) gave $t$-Bu-protected linear peptides 10a,b, which were cyclized using diphenylphosphoryl azide (DPPA)/ $\mathrm{NaHCO}_{3}$. Linear peptides 10a,b were converted to protected cyclic peptides 11a,b, respectively. In the cyclization process of linear peptide 10b, two minor side-products were obtained: an epimeric product and a ureal product, which was possibly produced via Curtius rearrangement. These were excluded during HPLC purification. Final deprotection of 11a,b provided the expected peptides 7a,b, respectively.

\subsection{Evaluation of $\mathrm{Fe}(\mathrm{III})$ coordinating activities of deferriferrichrysin and the derivatives}

Initially, Fe(III) coordinating activities of the siderophore peptides were evaluated by a competition experiment using ethylenediaminetetraacetic acid (EDTA). ${ }^{10}$ After the equimolar peptide and $\mathrm{Fe}(\mathrm{III})$ were dissolved in phosphate buffer ( $\mathrm{pH} 7.0)$, the mixture was treated with increasing concentrations of EDTA. The proportion of the Fe(III)-peptide complex in the presence of EDTA was calculated based on the absorbance intensity at the absorbance maximum of the complex (Figure 2). Ferrichrysin (2) formed a stable complex even in the presence of excess EDTA [the formation of $83 \%$ of the Fe(III)-peptide complex in the presence of three equivalents of EDTA]. Forty-seven percent of the $\mathrm{Fe}(\mathrm{III})$-deferriferrichrome (3) complex remained in the presence of three 
equivalents of EDTA. In contrast, derivatives $\mathbf{7 a}$ and $\mathbf{7 b}$ were easily deprived of Fe(III) by EDTA [ $22 \%$ and $14 \%$ of the $\mathrm{Fe}(\mathrm{III})$-peptide complexes remained in the presence of equimolar EDTA]. Thus, the order of Fe(III) coordinating activity for the siderophore peptides was deferriferrichrysin (1) $>$ deferriferrichrome (3) > cyclo(-Aho-Gly-Aho-Gly-Aho-Gly-) (7a) $\approx$ cyclo(-Aho-Ser-Aho-Ser-Aho-Ser-) (7b) at pH 7.0, ${ }^{11}$ suggesting that three consecutive Aho residues in deferriferrichrysin and naturally occurring siderophore peptides contributed noticeably to the high $\mathrm{Fe}(\mathrm{III})$ coordinating activity.

\subsection{Circular dichroism (CD) spectra of ferrichrysin and the derivatives}

For a hexacoordinate octahedral metal complex of three hydroxamate ligands, there are two possible geometric isomers, trans and cis. ${ }^{14,15}$ Each geometric isomer consists of $\Lambda$ and $\Delta$ optical isomers. ${ }^{15}$ All the reported X-ray crystal structures of hexadentate hydroxamate complexes show the cis configuration, and the optical chilarities have been determined by CD analysis. ${ }^{16-19}$ For example, it was proven by an X-ray diffraction study that ferrichrome A (4) exists in the cis- $\Lambda$ configuration, ${ }^{20}$ which was supported by the characteristic $465 \mathrm{~nm}$ positive band and the $360 \mathrm{~nm}$ negative band in the CD spectrum..$^{21}$

The Fe(III)-7a complex showed a similar CD spectrum to that of ferrichrysin (2) at $\mathrm{pH} 7.0$ (Figure 3), which shows that this species predominantly adopts the cis- $\Lambda$ configuration. In contrast, the Fe(III)-7b complex had a positive band at $370 \mathrm{~nm}$ and a negative band at $445 \mathrm{~nm}$, indicating that this complex predominantly exists in the $c i s-\Delta$ configuration. Since the cyclo(-Xaa-Gly-Xaa-Gly-Xaa-Gly-) scaffold is assumed to exhibit flexible conformations with a low number of intramolecular hydrogen bonds, ${ }^{22}$ the flexibility of peptide 7a may lead to Fe(III) complex adopting the usual $c i s-\Lambda$ configuration. In contrast, three side chains of L-Ser in $\mathbf{7 b}$ would restrict the backbone conformation due to the 1,3-allylic strain-like effect. ${ }^{23}$ This more rigid 
conformation of $\mathbf{7 b}$ would hinder the usual $c i s-\Lambda$ configuration of $\mathrm{Fe}(\mathrm{III})-\mathbf{7 b}$ complex, resulting in the characteristic $c i s-\Delta$ type coordinating configuration.

\subsection{Ultraviolet-visible (UV-vis) absorption spectra of ferrichrysin and the derivatives}

UV-vis spectra of Fe(III)-peptide complexes were acquired in pH-controlled buffers between 1.2 and 7.0 to reveal the $\mathrm{pH}$-dependent structural changes of the complexes. The UV-vis spectra of ferrichrysin (2) were nearly identical $\left(\lambda_{\max }=425 \mathrm{~nm}\right.$ ) over the $\mathrm{pH}$ range 1.2-7.0. Both Fe(III)-7a and $\mathrm{Fe}(\mathrm{III})-7 \mathbf{b}$ in $\mathrm{pH} 5.0$ and 7.0 solutions had similar spectra with absorbance $\lambda_{\max } \approx 425 \mathrm{~nm}$. Interestingly, red shifts of the visible $\lambda_{\max }$ of the spectra of $\mathrm{Fe}(\mathrm{III})-\mathbf{7 a}$ and $\mathrm{Fe}(\mathrm{III})-\mathbf{7 b}$ were observed at low $\mathrm{pH}$ values (Figure 4). This indicates that symmetric Fe(III) complexes with non-sequential Aho residues were easily protonated to change the structure of the complex,${ }^{24}$ which is in contrast to ferrichrysin.

The visual appearance of the Fe(III)-peptide complexes in three $\mathrm{pH}$ buffers are shown in Figure 5. A similar orange color was observed between the three ferrichrysin (2) solutions at $\mathrm{pH} 1.2,3.6$ and 7.0. In contrast, both solutions of Fe(III)-7a and Fe(III)-7b turned red at low pH. These corresponded to the UV-vis spectra of the solutions, suggesting that $\mathrm{Fe}(\mathrm{III})-\mathbf{7 a}$ and $\mathrm{Fe}(\mathrm{III})-\mathbf{7 b}$ represent potential $\mathrm{pH}$ indicators for acidic solutions.

\section{Conclusions}

In this study, we have carried out synthesis and comparative physicochemical analysis of two deferriferrichrysin analogs: cyclo(-Aho-Gly-Aho-Gly-Aho-Gly-) (7a) and cyclo(-Aho-Ser-Aho-Ser-Aho-Ser-) (7b) containing three interspersed Aho residues to investigate the structural basis of ferrichrysin siderophores. The siderophore/EDTA competition experiment revealed that the high Fe(III) coordinating activity of naturally occurring siderophore peptides was attributable to the three consecutive Aho residues. CD analysis demonstrated that the Fe(III)-7b complex exhibited a coordinating configuration not observed in other cyclic hexapeptide 
siderophores. Notably, characteristic pH-dependent spectral shifts in acidic media were observed for the Fe(III)-complexes of peptides $\mathbf{7 a}$ and $\mathbf{7 b}$, suggesting that these complexes could be useful as novel $\mathrm{pH}$ indicators.

\section{Experimental}

\subsection{Synthesis}

4.1.1. General Methods. ${ }^{1} \mathrm{H}$ NMR spectra were recorded using a JEOL ECA-500 spectrometer. Chemical shifts are reported in $\delta(\mathrm{ppm})$ relative to residual peak as an internal standard. ${ }^{13} \mathrm{C}$ NMR spectra were referenced to the $\mathrm{CD}_{3} \mathrm{CN}$ (in $\mathrm{D}_{2} \mathrm{O}$ ) or residual peak (in DMSO-d6) as an internal standard. Exact mass (HRMS) spectra were recorded on a JMS-HX/HX 110A mass spectrometer. Optical rotations were measured with a JASCO P-1020 polarimeter. For flash chromatography, Wakogel C-300E (Wako) was employed. For analytical HPLC, a COSMOSIL 5C18-ARII column $\left(4.6 \times 250 \mathrm{~mm}\right.$, Nacalai Tesque Inc., Kyoto, Japan) was employed with a linear gradient of $\mathrm{CH}_{3} \mathrm{CN}$ containing $0.1 \%(\mathrm{v} / \mathrm{v})$ TFA at a flow rate of $1 \mathrm{~mL} / \mathrm{min}$, and eluting products were detected by $\mathrm{UV}$ at $220 \mathrm{~nm}$. Preparative HPLC was performed using a COSMOSIL 5C18-ARII column $(20$ or $10 \times 250$ $\mathrm{mm}$, Nacalai Tesque Inc.) with a linear gradient of $\mathrm{CH}_{3} \mathrm{CN}$ containing $0.1 \%(\mathrm{v} / \mathrm{v}) \mathrm{TFA}$ at a flow rate of 8 or $4 \mathrm{~mL} / \mathrm{min}$, respectively.

4.1.2. cyclo(-Aho-Gly-Aho-Gly-Aho-Gly-) (7a). The protected linear peptide resin 9a was constructed by Fmoc-based solid-phase synthesis on H-Gly-(2-Cl)Trt resin $(0.64 \mathrm{mmol} / \mathrm{g}, 158 \mathrm{mg}$, $0.10 \mathrm{mmol})$. Fmoc-Gly-OH $(0.50 \mathrm{mmol})$ and Fmoc-Aho $(t-\mathrm{Bu})-\mathrm{OH}(0.30 \mathrm{mmol})$ were coupled using DIC-HOBt $\cdot \mathrm{H}_{2} \mathrm{O}$ (equivalent of Fmoc-amino acid) in DMF. Completion of each coupling reaction was ascertained using the Kaiser ninhydrin test. The Fmoc-protecting group was removed by treating the resin with $20 \%$ piperidine in DMF. The resulting protected peptide resin was subjected to $\mathrm{HFIP}-\mathrm{CH}_{2} \mathrm{Cl}_{2}(2: 8,20 \mathrm{~mL})$ treatment at room temperature for $2 \mathrm{~h}$. After filtration of the residual resin, the filtrate was concentrated under reduced pressure to give a crude linear peptide 10a. To a 
mixture of the resulting linear peptide in DMF $(40 \mathrm{~mL})$, DPPA $(53.9 \mu \mathrm{L}, 0.25 \mathrm{mmol})$ and $\mathrm{NaHCO}_{3}$ (42.0 $\mathrm{mg}, 0.50 \mathrm{mmol}$ ) were added at $-40{ }^{\circ} \mathrm{C}$. The mixture was stirred for $20.5 \mathrm{~h}$ with warming to room temperature. After filtration, the filtrate was concentrated under reduced pressure, followed by flash chromatography over silica gel with $\mathrm{CHCl}_{3}-\mathrm{MeOH}(9: 1)$ to give the crude protected cyclic peptide 11a. The crude peptide was treated with $\mathrm{CH}_{2} \mathrm{Cl}_{2}-\mathrm{TFA}-$ thioanisole $(10: 10: 1,3.65 \mathrm{~mL})$ at room temperature for $13 \mathrm{~h}$. The mixture was poured into ice-cold dry $\mathrm{Et}_{2} \mathrm{O}(30 \mathrm{~mL})$. The resulting powder was collected by centrifugation and washed three times with ice-cold dry Et ${ }_{2} \mathrm{O}$. The crude product was purified by preparative HPLC to afford the title compound as colorless freeze-dried powder (13.1 mg, 19\% from H-Gly-(2-Cl)Trt resin): $[\alpha]^{27} \mathrm{D}-11.5\left(c 0.82, \mathrm{H}_{2} \mathrm{O}\right) ;{ }^{1} \mathrm{H}-\mathrm{NMR}(500$ $\left.\mathrm{MHz}, \mathrm{D}_{2} \mathrm{O}\right) \delta: 1.57-1.96(\mathrm{~m}, 12 \mathrm{H}), 2.07-2.18(\mathrm{~m}, 9 \mathrm{H}), 3.56-3.71(\mathrm{~m}, 6 \mathrm{H}), 3.90(\mathrm{~d}, J=16.6 \mathrm{~Hz}, 3 \mathrm{H})$, $3.98(\mathrm{~d}, J=16.6 \mathrm{~Hz}, 3 \mathrm{H}), 4.35(\mathrm{dd}, J=6.3,6.3 \mathrm{~Hz}, 3 \mathrm{H}) ;{ }^{13} \mathrm{C} \mathrm{NMR}\left(125 \mathrm{MHz}, \mathrm{D}_{2} \mathrm{O}\right) \delta: 19.9(3 \mathrm{C})$, 22.8 (3C), 28.0 (3C), 43.3 (3C), 47.8 (3C), 54.0 (3C), 171.8 (3C), 174.4 (6C); HRMS (FAB): $m / z$ calcd for $\mathrm{C}_{27} \mathrm{H}_{46} \mathrm{~N}_{9} \mathrm{O}_{12}[\mathrm{M}+\mathrm{H}]^{+} 688.3260$; found: 688.3258 .

\subsection{3. cyclo(-Aho(t-Bu)-Ser(t-Bu)-Aho(t-Bu)-Ser(t-Bu)-Aho(t-Bu)-Ser(t-Bu)-) (11b). By the} identical procedure for the synthesis of peptide 11a and preparative HPLC purification, the expected peptide 11b was obtained as white freeze-dried powder $(21.6 \mathrm{mg}, 19 \%$ from $\mathrm{H}-\mathrm{Ser}(t-\mathrm{Bu})-(2-\mathrm{Cl}) \operatorname{Trt}$ resin): $[\alpha]^{26} \mathrm{D}-14.0\left(c\right.$ 0.94, MeOH); ${ }^{1} \mathrm{H}-\mathrm{NMR}\left(500 \mathrm{MHz}, \mathrm{DMSO}-d_{6}, 100{ }^{\circ} \mathrm{C}\right)$ $\delta: 1.17(\mathrm{~s}, 27 \mathrm{H}), 1.28(\mathrm{~s}, 27 \mathrm{H}), 1.56-1.81(\mathrm{~m}, 12 \mathrm{H}), 2.02(\mathrm{~s}, 9 \mathrm{H}), 3.50-3.71(\mathrm{~m}, 12 \mathrm{H}), 4.04-4.16(\mathrm{~m}$, $6 \mathrm{H}), 7.62(\mathrm{~d}, J=6.9 \mathrm{~Hz}, 3 \mathrm{H}), 7.70(\mathrm{~d}, J=5.7 \mathrm{~Hz}, 3 \mathrm{H}) ;{ }^{13} \mathrm{C} \mathrm{NMR}\left(125 \mathrm{MHz}, \mathrm{DMSO}-d_{6}, 100{ }^{\circ} \mathrm{C}\right) \delta$ : 20.6 (3C), 22.2 (3C), 26.8 (9C), 26.9 (9C), 28.0 (3C), 48.9 (3C), 53.3 (3C), 54.3 (3C), 60.3 (3C), 72.7 (3C), 81.6 (3C), 169.0 (3C), 170.5 (3C), 173.5 (3C); HRMS (FAB): $m / z$ calcd for $\mathrm{C}_{54} \mathrm{H}_{100} \mathrm{~N}_{9} \mathrm{O}_{15}[\mathrm{M}+\mathrm{H}]^{+}$1114.7333; found: 1114.7334 .

4.1.4. cyclo(-Aho-Ser-Aho-Ser-Aho-Ser-) (7b). By the identical procedure for the synthesis of peptide 7a, the expected peptide $7 \mathbf{b}$ was obtained as light yellow freeze-dried powder (12.3 mg, 
16\% from H-Ser( $t$-Bu)-(2-Cl)Trt resin): $[\alpha]^{26}{ }_{\mathrm{D}}-14.9\left(c\right.$ 0.90, $\left.\mathrm{H}_{2} \mathrm{O}\right) ;{ }^{1} \mathrm{H}-\mathrm{NMR}\left(500 \mathrm{MHz}, \mathrm{D}_{2} \mathrm{O}\right) \delta$ : $1.58-2.04(\mathrm{~m}, 12 \mathrm{H}), 2.06-2.18(\mathrm{~m}, 9 \mathrm{H}), 3.57-3.73(\mathrm{~m}, 6 \mathrm{H}), 3.88(\mathrm{dd}, J=11.5,4.6 \mathrm{~Hz}, 3 \mathrm{H}), 3.96(\mathrm{dd}$, $J=11.5,4.6 \mathrm{~Hz}, 3 \mathrm{H}), 4.36(\mathrm{dd}, J=8.6,5.2 \mathrm{~Hz}, 3 \mathrm{H}), 4.43(\mathrm{dd}, J=4.6,4.6 \mathrm{~Hz}, 3 \mathrm{H}) ;{ }^{13} \mathrm{C} \mathrm{NMR}(125$ MHz, $\left.\mathrm{D}_{2} \mathrm{O}\right) \delta: 19.8$ (3C), 22.9 (3C), 28.1 (3C), 47.8 (3C), 54.5 (3C), 56.8 (3C), 61.3 (3C), 172.0 (3C), 174.0 (3C), 174.4 (3C); HRMS (FAB): $m / z$ calcd for $\mathrm{C}_{30} \mathrm{H}_{52} \mathrm{~N}_{9} \mathrm{O}_{15}[\mathrm{M}+\mathrm{H}]^{+} 778.3577$; found: 778.3571 .

\subsection{EDTA/peptide competition experiment}

Peptide and $\mathrm{Fe}\left(\mathrm{NO}_{3}\right)_{3}\left[18.0 \mathrm{mM}\right.$ in $\left.0.1 \mathrm{mM} \mathrm{HNO}_{3}\right](0.2 \mathrm{mM}$ each) were dissolved in $100 \mathrm{mM}$ phosphate buffer ( $\mathrm{pH} 7.0$ ). To this Fe(III)-peptide complex solution, 0.10 to 3.0 equiv of EDTA was added. After incubation at $25{ }^{\circ} \mathrm{C}$ for $2-3$ days, UV-vis spectra were measured. The proportion of the Fe(III)-peptide complex was calculated as: [425 nm absorbance of the sample solution]/[425 nm absorbance of the control sample (no EDTA)].

\subsection{CD spectra}

CD spectra were recorded on a JASCO J-720 circular dichroism spectrometer at $20^{\circ} \mathrm{C}$. Peptide and $\mathrm{Fe}\left(\mathrm{NO}_{3}\right)_{3}\left[18.0 \mathrm{mM}\right.$ in $\left.0.1 \mathrm{mM} \mathrm{HNO}_{3}\right](0.5 \mathrm{mM}$ each $)$ were dissolved in $100 \mathrm{mM}$ phosphate buffer (pH 7.0).

\subsection{UV-vis spectra}

UV-vis spectra were recorded on a Shimadzu UV-2450 UV-vis spectrophotometer. Peptide and $\mathrm{Fe}\left(\mathrm{NO}_{3}\right)_{3}[18.0 \mathrm{mM}$ in $0.1 \mathrm{mM} \mathrm{HNO} 3](0.2 \mathrm{mM}$ each $)$ were dissolved in pH-controlled buffers: 50 $\mathrm{mM} \mathrm{HCl-KCl}$ buffer (for $\mathrm{pH}$ 1.2, 1.6 and 2.0); $50 \mathrm{mM}$ glycine- $\mathrm{HCl}$ buffer (for $\mathrm{pH}$ 2.4, 2.8, 3.2 and 3.6); $100 \mathrm{mM}$ acetate buffer (for $\mathrm{pH}$ 5.0); and $100 \mathrm{mM}$ phosphate buffer (for $\mathrm{pH}$ 7.0).

\section{Acknowledgements}


This work was supported by Grants-in-Aid for Scientific Research from the Ministry of Education, Culture, Sports, Science and Technology of Japan; and the Uehara Memorial Foundation. K.K. is grateful for Research Fellowships from the Japan Society for the Promotion of Science (JSPS) for Young Scientists.

\section{Supplementary data}

Supplementary data associated with this article can be found, in the online version, at \#\#\#\#\#\#\#. 


\section{References and notes}

1. For a review, see: Hider, R. C.; Kong, X. Nat. Prod. Rep. 2010, 27, 637.

2. Pierre, J. L.; Fontecave, M.; Crichton, R. R. BioMetals 2002, 15, 341.

3. Tadenuma, M.; Sato, S. Agric. Biol. Chem. 1967, 31, 1482.

4. Neilands, J. B. J. Am. Chem. Soc. 1952, 74, 4846.

5. Garibaldi, J. A.; Neilands, J. B. J. Am. Chem. Soc. 1955, 77, 2429.

6. Miller, M. J.; Malouin, F. Acc. Chem. Res. 1993, 26, 241.

7. Ji, C.; Miller, P. A.; Miller, M. J. J. Am. Chem. Soc. 2012, 134, 9898.

8. Miller, M. J.; Walz, A. J.; Zhu, H.; Wu, C.; Moraski, G.; Möllmann, U.; Tristani, E. M.; Crumbliss, A. L.; Ferdig, M. T.; Checkley, L.; Edwards, R. L.; Boshoff, H. I. J. Am. Chem. Soc. 2011, 133, 2076.

9. Kobayashi, K.; Oishi, S.; Kobayashi, Y.; Ohno, H.; Tsutsumi, H.; Hata, Y.; Fujii, N. Bioorg. Med. Chem. 2012, 20, 2651.

10. Hara, Y.; Akiyama, M. Inorg. Chem. 1996, 35, 5173.

11. Of note, their $\mathrm{Fe}(\mathrm{III})$ coordinating activities were previously reported; deferriferrichrysin $(\mathbf{1}, \mathrm{pK}$ $=30.0),{ }^{23}$ deferriferrichrome $(3, \mathrm{pK}=29.1),{ }^{23}$ cyclo(-Aho-Gly-Aho-Gly-Aho-Gly-) $(7 \mathrm{a}, \mathrm{pK}=$ $31.8) .^{24}$

12. Leong, J.; Raymond, K. N. J. Am. Chem. Soc. 1974, 96, 1757.

13. Drechsel, H.; Jung, G. J. Pept. Sci. 1998, 4, 147.

14. Norrestam, R.; Stensland, B.; Brändén, C. I. J. Mol. Biol. 1975, 99, 501.

15. Carrano, C. J.; Raymond, K. N. J. Am. Chem. Soc. 1978, 100, 5371.

16. van der Helm, D.; Baker, J. R.; Eng-Wilmot, D. L.; Hossain, M. B.; Loghry, R. A. J. Am. Chem. Soc. 1980, 102, 4224.

17. Wong, G. B.; Kappel, M. J.; Raymond, K. N.; Matzanke, B.; Winkelmann, G. J. Am. Chem. Soc. 1983, 105,810 
18. Zalkin, A.; Forrester, J. D.; Templeton, D. H. J. Am. Chem. Soc. 1966, 88, 1810.

19. Abu-Dari, K.; Raymond, K. N. J. Am. Chem. Soc. 1977, 99, 2003.

20. Tanizawa, K.; Okumura, K.; Itoh, H.; Hatanaka, Y.; Kanaoka, Y. Chem. Pharm. Bull. 1986, 34, 4001.

21. Haubner, R.; Finsinger, D.; Kessler, H. Angew. Chem. Int. Ed. 1997, 36, 1374.

22. Dhungana, S.; Harrington, J. M.; Gebhardt, P.; Möllmann, U.; Crumbliss, A. L. Inorg. Chem. 2007, 46, 8362 .

23. Anderegg, G.; L'Eplattenier, F.; Schwarzenbach, G. Helv. Chim. Acta. 1963, 46, 1409.

24. Akiyama, M.; Katoh, A.; Mutoh, T. J. Org. Chem. 1988, 53, 6089. 


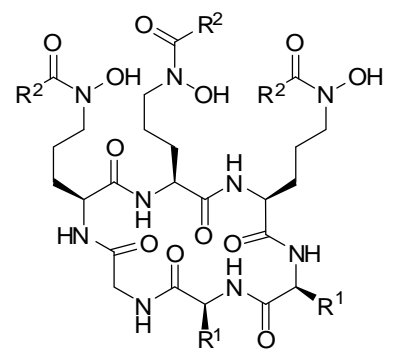

deferriferrichrysin (1): $\mathrm{R}^{1}=\mathrm{CH}_{2} \mathrm{OH}, \mathrm{R}^{2}=\mathrm{CH}_{3}$ deferriferrichrome (3): $\mathrm{R}^{1}=\mathrm{H}, \mathrm{R}^{2}=\mathrm{CH}_{3}$

deferriferrichrome $A(4): R^{1}=H, R^{2}=$<smiles>CC(C)=CC(C)=CCC(=O)O</smiles><smiles>CCOc1cccc(C(=O)NCCCC(CCCNC(=O)c2cccc(O)c2O)(CCCNC(=O)c2cccc(O)c2O)NC(=O)CCC(=O)O)c1O</smiles>

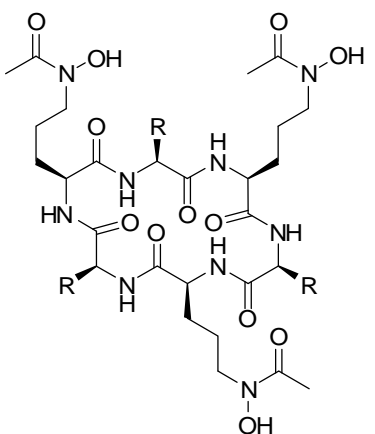

cyclo(-Aho-Gly-Aho-Gly-Aho-Gly-) (7a) : R = H cyclo(-Aho-Ser-Aho-Ser-Aho-Ser-) (7b) $: \mathrm{R}=\mathrm{CH}_{2} \mathrm{OH}$

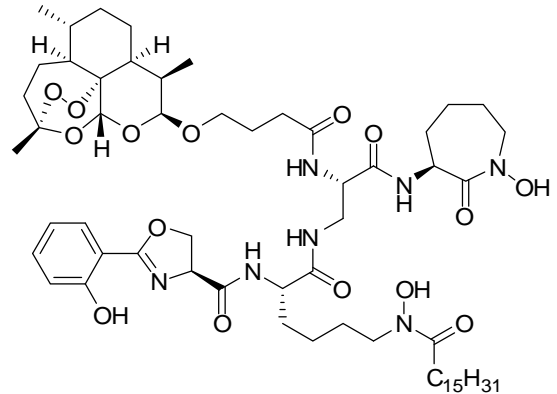

mycobactin-artemisinin conjugate (6)

Figure 1. Structures of siderophore and the derivatives. 


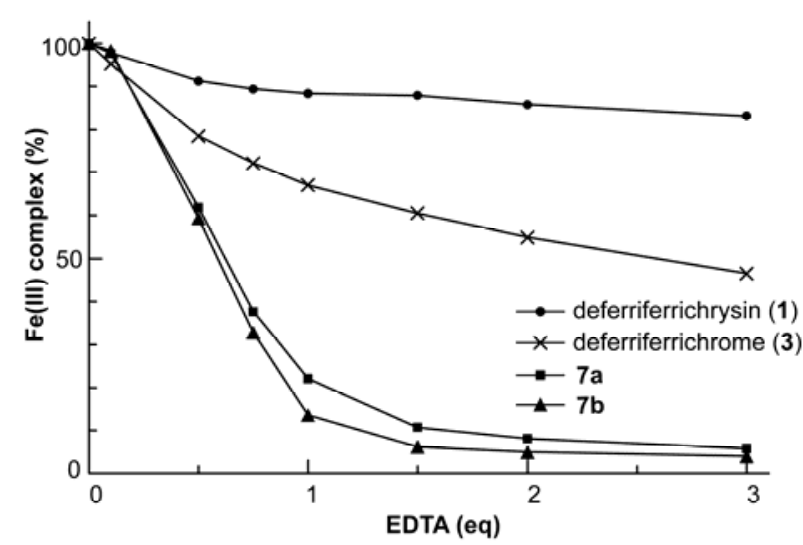

Figure 2. Competition experiments between siderophore peptides and EDTA for Fe(III) coordinating activity at $\mathrm{pH} 7.0$. 


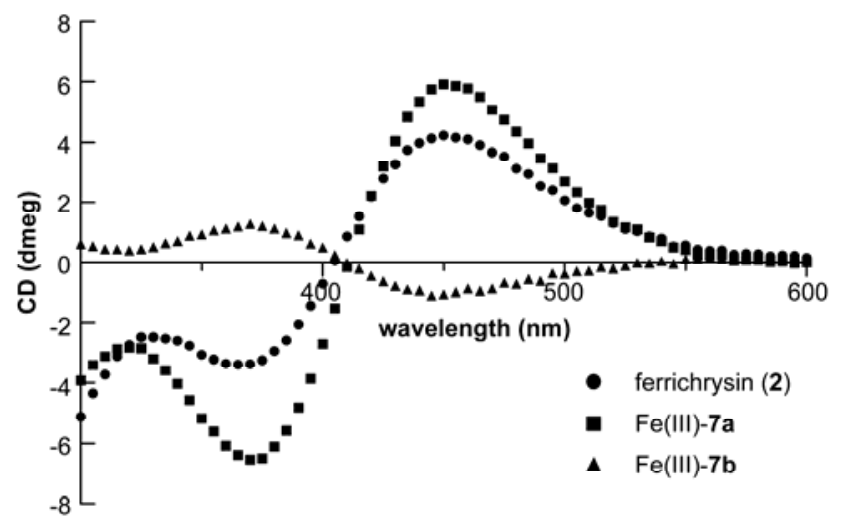

Figure 3. CD spectra of Fe(III) complexes of siderophore peptides. 

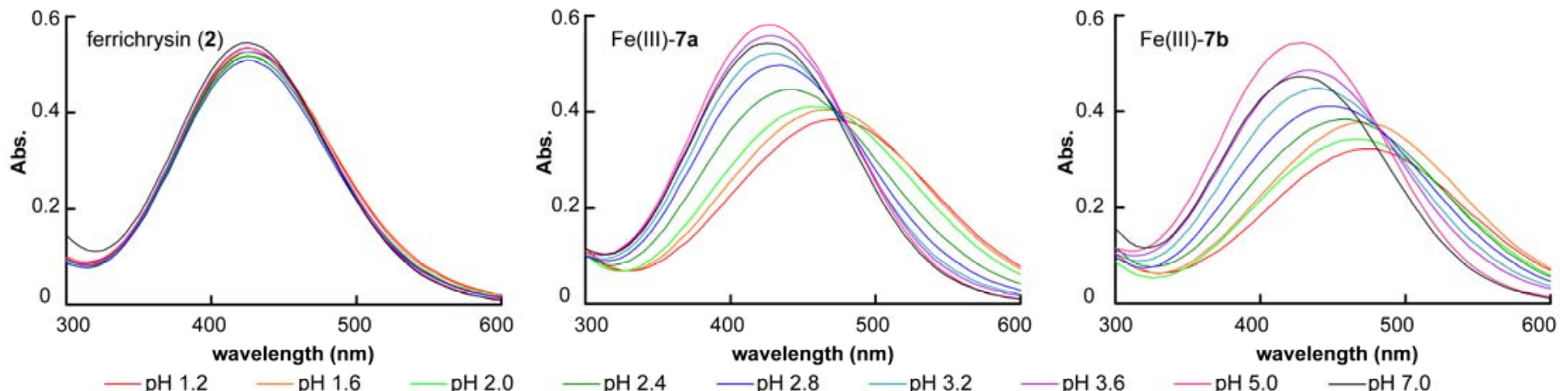

Figure 4. UV-vis spectra of Fe(III) complexes of siderophore peptides. 


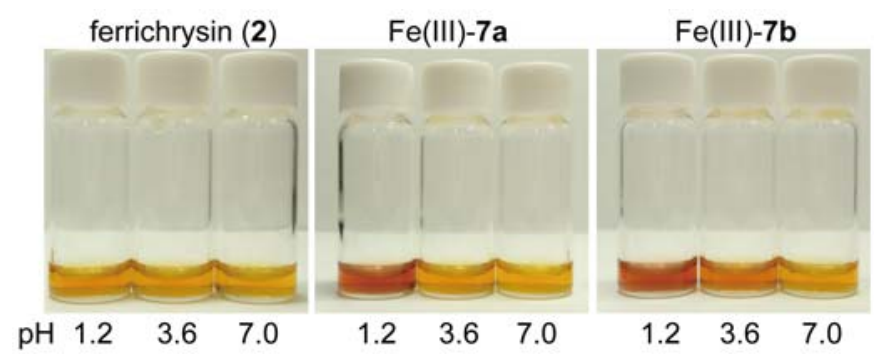

Figure 5. Appearance of $\mathrm{Fe}(\mathrm{III})$-peptide complex solutions.

Peptide and Fe(III) (1.0 mM each) were dissolved in pH-controlled buffers: $50 \mathrm{mM} \mathrm{HCl-KCl}$ buffer (for $\mathrm{pH} 1.2$ ); $50 \mathrm{mM}$ glycine-HCl buffer (for $\mathrm{pH}$ 3.6); and $100 \mathrm{mM}$ phosphate buffer (for $\mathrm{pH}$ $7.0)$. 


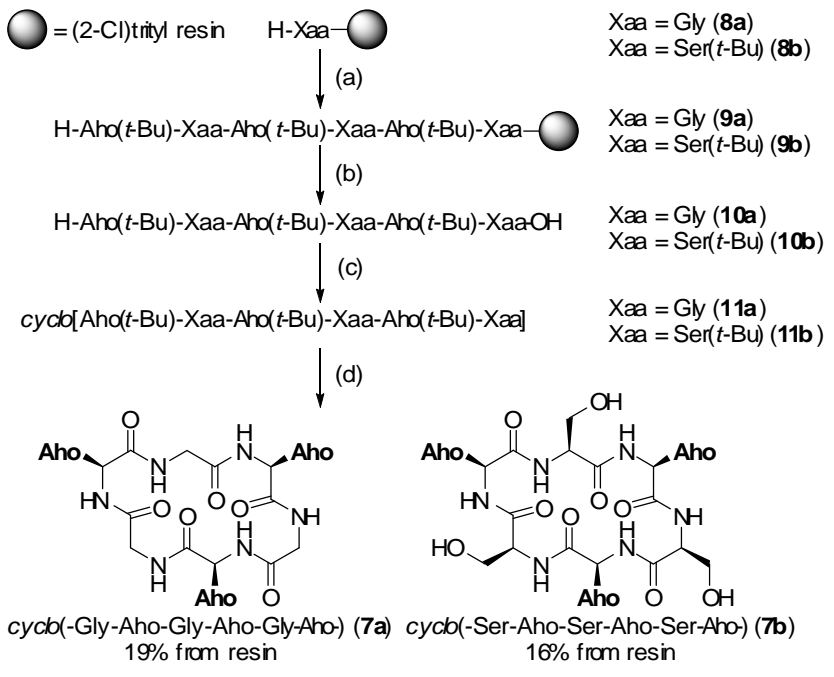

Scheme 1. Synthesis of deferriferrichrysin derivatives.

Reagents and conditions: (a) Fmoc-based SPPS; (b) HFIP, $\mathrm{CH}_{2} \mathrm{Cl}_{2}, \mathrm{rt}, 2$ h; (c) DPPA, $\mathrm{NaHCO}_{3}$, DMF, $-40{ }^{\circ} \mathrm{C}$ to $\mathrm{rt}$; (d) TFA, $\mathrm{CH}_{2} \mathrm{Cl}_{2}$, thioanisole, $\mathrm{rt}(19 \%$ from 8a, $16 \%$ from 8b); Aho = $N^{\delta}$-acetyl- $N^{\delta}$-hydroxy-L-ornithine. 